\title{
Perceptions of Teachers About Teacher Leader- SHIP: A Systematic Literature ReVieW
}

\author{
Kamran Akhtar Siddiqui(D), Zulfiqar Ali Chachar (D), Zuhaib Zafar (D), Masood \\ Ahmed DooliD and Akash Kumar(D)
}

Teacher leadership is pivotal for the development of educational institutions. However, teachers' perceptions about teacher leadership have been under explored. In this study, the researchers review sixteen studies conducted in the USA, South Africa and other European, Asian, and Middle Eastern countries. Four themes emerged after analysis of the texts: perceptions of teachers about teacher leadership practices, factors influencing teacher leadership, teacher leadership development, and barriers to teacher leadership. Results show that teacher leaders are engaged in mentoring teachers, coordinating with administration, curriculum development and implementation, and subject matter development. The physical environment of the school, teachers' age, experience, qualification, and support from the administration also influences teachers' perceptions about teacher leadership. Teacher leadership development is influenced by teachers' own beliefs, principals' support and teachers' professional development. Some barriers to teacher leadership are also discussed in this paper.

\section{KEYWORDS: Leadership, Teacher Leadership, Teachers Perception}

\author{
Kamran Akhtar Siddiqui $\square$ \\ Department of Mathematics and Social Sciences, Sukkur IBA University, Pakistan. \\ Email: Kamran.akhtar@iba-suk.edu.pk. ORCID: https://orcid.org/0000-0002-7507-6072 \\ Zulfigar Ali Chachar \\ Department of Mathematics and Social Sciences, Sukkur IBA University, Pakistan. \\ Email: zchachar@iba-suk.edu.pk.ORCID: https://orcid.org/0000-0002-6724-7222 \\ Zuhaib Zafar \\ Department of Education, Jiangsu University, Zhenjiang, China. \\ Email: zuhaib.zafar@iba-suk.edu.pk.ORCID: https://orcid.org/0000-0003-4877-7372 \\ Masood Ahmed Dool \\ Department of Education, IBA University, Sukkur, Pakistan. \\ Email: masood.mphil18@iba-suk.edu.pk. ORCID: https://orcid.org/0000-0001-8831-0430 \\ Akash Kumar \\ Department of Education, IBA University, Sukkur, Pakistan. \\ Email: aakash.mphil18@iba-suk.edu.pk.ORCID: https://orcid.org/0000-0002-4070-7559
}




\section{INTRODUCTION}

The world is going through social, cultural, and technological changes that have influenced every walk of life. Education is no exception. These changes have posed some challenges to school education, such as inclusiveness, identity, and integration of ICT for beneficial purposes. These challenges can only be overcome through effective leadership in academic institutions. Since school level leadership usually gets linked with school heads, authority, and control, teachers focus exclusively on teaching in school management (Katzenmeyer \& Moller, 2009). However, in the modern-day world, leadership in academic institutions is not restricted to school heads who control or supervise institutions from their offices. In fact, teachers have emerged as a vital force in dealing with novel and challenging situations to improve and sustain quality education in schools. Thus, teacher leadership is an area of great significance for researchers.

Teacher leadership does not focus on classroom teaching only, but it is about matters inside and outside the premises of the school. Since researchers have not reached an agreement on the definition of teacher leadership (Neumerski, 2013), the concept is defined in various ways. According to Cosenza (2015), The Institute for Educational Leadership puts forward quite general and advanced definition of Teacher Leadership. It says, "Teacher leadership is not necessarily about power, but about teachers expanding their presence outside the classroom by seeking other challenges and growth opportunities." Likewise, Olujuwon and Perumal (2014) define teacher leadership as a mechanism by which teachers impact their peers as well as other members of the school system personally or jointly as they seek to create effective teaching and learning practices. This means that the teacher leaders possess a set of specific skills that are not only effective in the classroom but also enable them to make an impact outside the classroom.

However, a host of teachers who exercise teacher leadership do not consider themselves leaders, as the term assumes that 'leader' refers to teachers who have formal jobs in positions, for instance, school heads (Angelle \& Dehart, 2011). This influences their roles as teacher leaders. In general, perceptions of teachers about teacher leadership impact school performance. Therefore, teachers must understand teacher leadership because, as Siti (2011) states, leadership practices can improve the quality of student learning. Thus, perceptions of teachers about teacher leadership hold great importance, and they must be studied if the education institutions want to benefit from their teacher leadership. While school leadership has been studied in the past decades, teacher leadership has received very little attention. Given this importance of the topic and the need for research, this literature review aims to study, integrate, and synthesize the perceptions of school teachers about teacher lead- 
ership. In brief, this literature review seeks to answer the following research question.

Q. What are the perceptions of teachers about teacher leadership?

The rest of the paper is structured in the following manner. First, the methodological approach used in the review process is described. Then the findings of the literature review are discussed, and answers to the abovementioned research questions are offered.

\section{Research Methodology}

To determine the qualified research studies, an electronic search in Google Scholar was conducted. Web of Science and Scopus databases were given preference to obtain the most reliable and credible studies. The search parameters "Teacher leader" and "Instructional Head" were used. Besides, the BOOLEAN Operators were also employed to get access to the most relevant literature for the study. However, studies on teacher leadership that used different terminology such as 'faculty leadership' or 'school leadership' were not selected. It was done because "search terms faculty leadership and school leadership are strongly associated with the leadership of principals and not with the leadership of 'regular' teachers whose primary tasks are classroom responsibilities" (Schott, Roekel, \& Tummers, 2020) .

Moreover, search terms such as "perceptions of teachers about teacher leadership" or "teachers' perspectives about teacher leadership" were also used to obtain more relevant results for this literature review. The research studies searched and later selected were all in English language only and they have been published in various peer-reviewed journals from 2010 to 2020.

\section{CRITERIA FOR INCLUSION AND EXCLUSION}

For this literature review, an inclusion criteria comprising six points was set which was inspired by systematic literature reviews conducted earlier particularly by Vries, Bekkers, and Tummers (2016).

1. Centrality of Topic: Articles with the focus on perspectives or perceptions of teachers about teacher leadership were selected whereas those were omitted which discussed teacher leadership with any other construct.

2. Respondents: Since the literature review revolves around teachers' perspectives about teacher leadership, only those studies were shortlisted which had participants as active teachers who along with teaching were engaged in certain leadership roles. 
3. Study Design : All study designs (case studies, experimental etc.) were allowed to be included for the purpose of the review.

4. Year of Publication : The studies were selected that published from 2010 to 2020 so that the recent findings can be brought at one place through this review.

5. Language: Articles in English language only were searched and selected.

6. Publication Status : It was ensured that all studies used for the review purpose must have been published in 'peer-reviewed' academic journals so that quality findings could be obtained.

\section{Selection Process}

In terms of this review, it can be considered a drawback that there is a shortage of work on exploring the leadership of teachers in both domestic and international literature. Therefore, it was extremely challenging to select the most relevant studies for the purpose of this literature review research. So, critical reading of the studies was done to choose the best suitable studies keeping in view the inclusion criteria. Hence, the following sixteen studies (see Table 1) were shortlisted to be included in the literature review.

\section{Table 1}

\section{Thematic Division of Articles.}

\begin{tabular}{llc}
\hline S. No. & Themes & No. of Articles \\
\hline 1. & $\begin{array}{l}\text { Perceptions of teachers about teacher lead- } \\
\text { ership practices }\end{array}$ & 04 \\
2. & $\begin{array}{l}\text { Perceptions of teachers about Factors influ- } \\
\text { encing teacher leadership }\end{array}$ & 04 \\
3. & $\begin{array}{l}\text { Perceptions of teachers about teacher lead- } \\
\text { ership development }\end{array}$ & 05 \\
Perceptions of teachers about barriers to & 03 \\
\hline & \multicolumn{1}{c}{ Total } \\
\hline
\end{tabular}

\section{Coding Process}

A literature review matrix was created to extract specific details from the selected articles. The articles were critically read, and particular fragments 
of the text were coded in the light of the research question. For example, the coded text included the research questions or aims, context of the studies, research design and methodology, research participants and the perceptions of the teachers found in the study.

\section{Results AND Discussion}

Through a rigorous study of research studies, sixteen studies were finally selected as a research sample, and were categorized into four themes. A detailed description of each theme is discussed below.

\section{Theme 1: Teachers' Perceptions of Teacher Leadership practices}

Table 2

Studies on Teachers' Perceptions of Teacher Leadership Practices.

\begin{tabular}{|c|c|c|c|}
\hline Author \& Year & Design/Methodology & Tools & $\begin{array}{l}\text { Context \& } \\
\text { Participants }\end{array}$ \\
\hline Aliakbari (2014) & Descriptive Survey & Survey & $\begin{array}{c}\text { Iran } 213 \text { School } \\
\text { Teachers }\end{array}$ \\
\hline Struyve (2014) & $\begin{array}{l}\text { Multiple Case } \\
\text { Study }\end{array}$ & $\begin{array}{c}\text { Semi- } \\
\text { Structured } \\
\text { Interviews }\end{array}$ & $\begin{array}{c}\text { Flanders } 26 \\
\text { Primary \& } \\
\text { Secondary } \\
\text { Teacher }\end{array}$ \\
\hline Grant (2010) & Survey & $\begin{array}{l}\text { Large-Scale } \\
\text { Survey }\end{array}$ & $\begin{array}{l}\text { South Africa } \\
\text { 1,055 Post } \\
\text { Level-One } \\
\text { Teachers From } \\
\text { Across The } 81 \\
\text { Schools }\end{array}$ \\
\hline Lai (2014) & Mixed Method & $\begin{array}{l}\text { Questionnaire } \\
\text { Survey, } \\
\text { Focus Group } \\
\text { Interviews }\end{array}$ & $\begin{array}{l}\text { Hong Kong } \\
\text { Teachers From } \\
09 \text { Secondary } \\
\text { Schools }\end{array}$ \\
\hline
\end{tabular}

The first theme that emerged as a result of literature search and analysis was teacher perceptions of teacher leadership practices. Based on the inclusion criteria, four studies were selected (see Table 2) for this theme. The studies have been conducted between 2010 and 2020 in different contexts such as Iran, Honk Kong, Flanders and South Africa. So, the voices of teachers 
about teacher leadership practices can be analysed from varying contexts with completely different political and educational conditions. All the above studies have been published in renowned journals on leadership. For example, studies of Aliakbari and Sadeghi (2014) and Lai and Cheung (2015) were published in journal of Educational Management Administration \& Leadership by SAGE, study of S Struyve, Meredith, and Gielen (2014) was published in the Journal of Educational Change by Springer, and the study of Grant, Gardner, Kajee, Moodley, and Somaroo (2010) was published in the South African Journal of Education. Besides, two of the selected studies followed survey approach, one mixed method and one qualitative approach. As for the sample, the qualitative study had a sample of twenty-six (26) participants whereas the sample of quantitative studies ranged from one hundred to one thousand teachers. The studies used surveys, semi-structured and focus group interviews to produce very useful findings concerning teachers' perceptions about teacher leadership practices. Keeping in view the repute of these research journals and the data collection methods used, the findings of the studies can be trusted and can be used to make useful deductions.

In the study of Aliakbari and Sadeghi (2014), the results from the analysis of three one-sample t-tests for primary, middle and high schools show that teacher leadership is sometimes and often conducted in the sample schools. These findings also indicate that teachers are pivotal for functioning of schools and that they are often involved in decision-making on important matters for schools and students. In this regard, Struyve et al. (2014) report that in Flemish schools teacher leaders known as coordinators are given responsibilities such as "providing special needs care to pupils, guiding teachers how to deal with those pupils in the classroom, organizing and leading teacher meetings, and providing administrative support (school schedules, school regulations, ICT)". This reflects that teacher perform many management tasks in their roles as leaders. This impression can be reinforced by the study of Grant et al. (2010) which report that around $71.7 \%$ of the teachers were confident of playing roles of teacher leaders. Around $71.5 \%$ teachers claimed to update their pedagogical knowledge and skills for classroom practice. Only $51 \%$ of the teachers shared their expertise with their colleagues and mentored them whereas mere 30.5\% were involved actively in in-school decision making process. Similarly, Lai and Cheung (2015) reveal through their mixed method study that teacher leaders actively attended professional development trainings which they believed was necessary for proper curriculum implementation. These teacher leaders were also involved in subject matter development and timetable organization.

It can be interpreted from these findings that practices of teacher leaders stretch over both administrative and academic domains. Teacher leaders have adopted different roles for proper functioning of schools. For instance, teacher leaders perform certain administrative tasks and are a part of decision-making 
process (Aliakbari \& Sadeghi, 2014), and teacher leaders work as a bridge between teachers and students (Struyve et al., 2014), or teachers and parents. Along with that, the teachers remain involved in their own professional development and curriculum implementation (Grant et al., 2010; Lai \& Cheung, 2015) . These multifarious practices of teacher leaders in various contexts signify the significance of teacher leaders to operate schools efficiently.

\section{Theme 2: Factors Influencing Teachers' Perception of Teacher Leader- ship}

Table 3

Studies on Factors Influencing Teachers' Perception of Teacher Leadership.

\begin{tabular}{lccc}
\hline Author \& Year & $\begin{array}{c}\text { Design/ } \\
\text { Methodology }\end{array}$ & Tools & $\begin{array}{c}\text { Context \& } \\
\text { Participants }\end{array}$ \\
\hline Sawalhi (2019) & Qualitative & $\begin{array}{c}\text { Semi- } \\
\text { Structured } \\
\text { Interviews }\end{array}$ & Qatar 06 \\
Chien (2018) & Mixed Method & $\begin{array}{c}\text { Questionnaire } \\
\text { Survey, Focus }\end{array}$ & $\begin{array}{c}10 \text { Taiwanese } \\
\text { Elementary } \\
\text { School English }\end{array}$ \\
& & Group & Teachers \\
Aliakbari (2014) & Descriptive & Survey & 213 School (El, \\
& Survey & & Mid, High) \\
& Causal & Large-Scale & Teachers; Iran \\
Angelle (2011) & Survey & Respondents \\
& Comparative & & Included 84\% \\
& & & Female And \\
& & & $16 \%$ Male \\
& & & Respondents. \\
& & & USA \\
\hline
\end{tabular}

The second theme that emerged after the literature search and analysis in the light of inclusion criteria was factors influencing teachers' perception of teacher leadership. For this theme, five studies (see Table 3) were shortlisted after rigorous process of review. Like other studies, these studies are also published in well-reputed journals. For instance, study of S Sawalhi and Chaaban (2019) is published in International Journal of Leadership in Education 
by Taylor and Francis. Three studies are published in SAGE journals. Study of Chien (2018) is published in Research in Education, study of Aliakbari and Sadeghi (2014) in Educational Management Administration \& Leadership and study of Angelle and Dehart (2011) in NASSP Bulletin by SAGE. One study used mixed method, one used qualitative design, one used causal comparative and one used descriptive survey approach to study the factors. Surveys, semistructured interviews and focus group interviews were employed to collect data from participants who ranged from six to over six hundred in number.

Sawalhi and Chaaban (2019) conducted a mixed method study on how participation in a practicum experience influences six student teachers' perceptions about teacher leadership in the context of Qatar. The findings revealed that student teachers considered "verbal appraisal and support from school" to be factors the influenced teacher leadership. Chien (2018), on the other hand, studied the extent to which the background of elementary English teachers influenced their perceptions of teacher leadership in the Taiwanese context. He found that teachers' age, teaching experience and the school size influenced their perceptions of teacher leadership. Their teaching experience and their knowledge and skills in leadership has the strongest correlation (0.68). Likewise, school size and the perceptions related to decision making stood at 0.55 . On the other hand, Aliakbari and Sadeghi (2014) found in their study on Iranian teacher leaders that there was no significant difference in their perceptions of teacher leadership on the basis of age and teaching experience, which was 0.492 and 0.072 respectively. However, Angelle and Dehart (2011) explored perceptions of (Elementary, Middle and High school) teachers in seven states of USA. Since this was a large-scale survey, the findings reported statistical differences between teachers' perceptions about teacher leadership based on experience, degree and position.

What can be inferred from the findings in this theme is that teachers' perceptions about teacher leadership are highly influenced by factors of experience, position and physical environment. However, the most important factor seems to be the age of teacher leaders. As it can be seen in the study of Sawalhi and Chaaban (2019), young (student) teacher leaders report verbal praise and support from authorities as a motivational factor for their teacher leadership. Whereas the perceptions of other professional teachers (Aliakbari \& Sadeghi, 2014; Angelle \& Dehart, 2011; Chien, 2018) are more hinged on concrete factors such as school size, degree and position. Therefore, a longitudinal study can be carried out on teacher leaders to see what factors influence them at different points of time during their career. Moreover, it can also be studied how these factors influence the perceptions and practices of teacher leaders at different stages. 


\section{Theme 3: Teachers' Perception of Teacher Leadership Development}

Table 4

Studies on Teachers' Perception of Teacher Leadership Development.

\begin{tabular}{lccc}
\hline Author \& Year & $\begin{array}{c}\text { Design/ } \\
\text { Methodology }\end{array}$ & Tools & $\begin{array}{c}\text { Context \& } \\
\text { Participants }\end{array}$ \\
\hline Sinha (2017) & $\begin{array}{c}\text { Multiple Case } \\
\text { Study }\end{array}$ & $\begin{array}{c}\text { Application } \\
\text { Discussion } \\
\text { Forums Action } \\
\text { Plans Progress }\end{array}$ & $\begin{array}{c}\text { Three } \\
\text { Individual } \\
\text { Cases USA }\end{array}$ \\
& & Reports Blogs & \\
Szeto (2017) & Case Study & Interviews Life & \\
& Design & Store Exercise & \\
Cheng (2016) & Qualitative, & Semi-Structured & 20 Beginning \\
& Longitudinal & Interviews & Teachers; \\
& & & Tong Kong \\
Ross (2011) & Qualitative & Interviews & Hong Kong \\
& & & Graduates; \\
Nicolaidou & Qualitative & Semi-Structured & Five Cases \\
(2010) & & Interviews & Cyprus \\
\hline
\end{tabular}

The third theme that developed as a result of internet search and analysis of studies was teachers' perception of teacher leadership development. Five quality studies (see Table 4) were selected to further explore this theme. Three studies (Cheng \& Szeto, 2016; Ross et al., 2011; Sinha \& Hanuscin, 2017) have been published in Teaching and Teacher Education by Elsevier, one study is published in Teacher Development: An international journal of teachers' professional development by Taylor and Francis and one study in International Journal of Leadership in Education by Taylor and Francis. Interestingly enough, all the studies finalized for this theme are qualitative and have employed (semi-structured) interviews except the study of Sinha and Hanuscin (2017) who have employed multiple data sources besides interviews. Since qualitative studies yield rich data and demand rigorous analysis, the participants range from five to twenty maximum.

Sinha and Hanuscin (2017) conducted a study on three teachers in American context to investigate the process and pathway of their leadership devel- 
opment. They found that teachers 'leadership views, identity and leadership practices' play crucial role in their development as teacher leaders. Initially, the teachers did not consider themselves as leaders and associated leadership with formal roles and offices. As their views about leadership changed with professional development, they began to perceive themselves as leaders and, thus, they adopted leadership roles outside the classroom as well.

Likewise, Szeto and Cheng (2018) conducted a study on 20 beginning teachers in Hong Kong to examine the role of principals in development of teacher leaders. Their findings suggest that the teachers appreciated the role of principals who communicated with them formally or informally about their dayto-day roles. Besides, teachers appreciated the principals' role in facilitating them for their professional development related to curriculum, pedagogy etc.

Similarly, Cheng and Szeto (2016) explored the perceptions of 20 novice teachers about principal's role in teacher leadership development. The findings report that principals always encouraged teachers to 'go ahead' with their proposals for innovation in classroom teaching, conversed with them informally to encourage them to initiate learning communities with like-minded teachers, and assigned them formal subject leader roles. So, whether by principal-delegated or self-initiated activities, novice teachers assumed role of teacher leaders.

While Sinha and Hanuscin (2017) highlighted the role of professional development in development of teacher leadership, Cheng and Szeto (2016) and Szeto and Cheng (2018) threw light on the facilitation by principals in development of teacher leadership. On the other hand, Ross et al. (2011) underscore role of teacher leadership development program designed for teachers in American context. Their findings indicate that teachers' perceptions about leadership greatly transformed as they began perceiving learning as a communal goal. Besides, teachers realized the importance of sharing success and failure with colleagues and adopting roles of 'teacher consultants' for collective benefits.

In the same way, Nicolaidou (2010) studied the perceptions of teachers about teacher leadership in Cyprus. The results revealed that teachers had to adopt formal or informal leadership roles when the school had to organize an event. The participants commented that the circulars were disseminated about the functions. Sometimes, everything was pre-planned, and they had to follow; at other times they had to mutually decide about their roles and what to do in a particular event. Besides, participants opined that such duties were for their development and the development of schools.

These studies highlight a few extremely essential components for development of teacher leadership. Firstly, teachers' own beliefs are of great impor- 
tance. They can help teachers assume leadership roles. Second, the role of professional development is of paramount importance as it has the ability to transform beliefs which can be seen in the study of Sinha and Hanuscin (2017). Third, the role of principals is undeniable in the development of teacher leaders as ultimately it is the principals who assigns tasks, and duties to teachers in most cases. Fourth, once a teacher becomes a teacher leader, participation in teacher leadership development program becomes must. Therefore, studies should be conducted to prepare a model comprising variables for the development of teacher leaders. The model can help examine the role of these different variables in the development of teacher leaders.

Theme 4: Teachers' Perception About Barriers to Teacher Leadership

Table 5

Studies On Teachers' Perception About Barriers to Teacher Leadership.

\begin{tabular}{|c|c|c|c|}
\hline Author \& Year & $\begin{array}{l}\text { Design/ } \\
\text { Methodology }\end{array}$ & Tools & $\begin{array}{l}\text { Context \& } \\
\text { Participants }\end{array}$ \\
\hline Jacobs (2016) & Mixed Method & $\begin{array}{c}\text { Survey; Semi- } \\
\text { Structured } \\
\text { Interviews }\end{array}$ & $\begin{array}{c}177 \text { Teacher } \\
\text { Leaders, USA }\end{array}$ \\
\hline $\begin{array}{l}\text { Margolis and } \\
\text { Huggins (2012) }\end{array}$ & Qualitative & $\begin{array}{c}\text { Semi- } \\
\text { Structured } \\
\text { Interviews }\end{array}$ & $\begin{array}{c}\text { Six Teachers, } \\
\text { USA }\end{array}$ \\
\hline Nicolaidou (2010) & Qualitative & $\begin{array}{l}\text { Semi- } \\
\text { Structured } \\
\text { Interviews }\end{array}$ & $\begin{array}{c}\text { Five Cases } \\
\text { Cyprus }\end{array}$ \\
\hline Grant (2010) & Survey & $\begin{array}{l}\text { Large-Scale } \\
\text { Survey }\end{array}$ & $\begin{array}{c}\text { South Africa } \\
\text { 1,055 Post } \\
\text { Level-One } \\
\text { Teachers From } \\
\text { Across the } 81 \\
\text { Schools }\end{array}$ \\
\hline
\end{tabular}

The fourth theme developed through extensive literature search and critical analysis was teachers' perception about barriers to teacher leadership. Four key studies (Grant et al., 2010; Jacobs, Gordon, \& Solis, 2016; Margolis \& Huggins, 2012; Nicolaidou, 2010) were selected (see Table 5) on the basis of inclusion criteria and were studied closely to make meaning of them. All three studies were published in renowned journals, for example, the studies of Jacobs 
et al. (2016)and M Margolis and Huggins (2012) were published in Journal of School Leadership, the study of Nicolaidou (2010) was published in Teacher Development: An international journal of teachers' professional development by Taylor and Francis, and the study of Grant et al. (2010) in South African Journal of Education. All the four studies were conducted in different contexts such as USA, Cyprus and South Africa respectively. One study used survey approach, one used mixed method approach whereas two of them were qualitative in nature. The participants varied from five to a thousand teacher leaders. Given the diversity of contexts, wide range of participants and use of interviews, the findings related to the barriers in teacher leadership are significant.

Jacobs et al. (2016) conducted their mixed method study on 177 teacher leaders in USA to identify the barriers to teacher leadership. The results reveal that heavy workload, lack of time, teachers' resistance to change and role ambiguity were the key barriers associated with teacher leadership. Likewise, Nicolaidou (2010) studied the perceptions of teachers about teacher leadership in Cyprus. The results revealed that teacher leaders highlighted power-related issues as barrier to teacher leadership. The participants commented that senior teachers "looked down on" their role as teacher leaders whereas young or fresh teachers looked towards them for help and guidance.

Similarly, Grant et al. (2010) on the basis of their survey imply that teacher leaders in South African context experienced barriers like hierarchical structure and autocracy of principals. Researchers reported that teacher leaders were not given authority and democratic norms were not in practice in those schools due to the history of inequality and control. Besides, the respondents reported that principals also practised autocracy which resulted in unnecessary hindrance in practising teacher leadership. In the same way, Margolis and Huggins (2012) conducted a longitudinal qualitative study in USA to examine teacher leaders' role development and definition by looking at one emergent model of distributed leadership: the hybrid teacher leaders (HTLs). The findings revealed that unclear definition of HTLs roles, transience of leadership, and too many initiatives for HTLs to handle were the key barriers to teacher leadership.

It can be drawn from the above studies that the teacher leaders face issue from two key sides: their own profession, colleagues and higher officials. Teacher leadership is a huge responsibility which is seldom given weightage in schools and teachers have to deal with additional responsibilities the teacher leadership role brings with it Zydziunaite, Kontrimiene, Ponomarenko, and Kaminskiene (2020). Besides, teacher leaders must face the conservative mindset of (senior) teachers sometimes as they do not like to be guided or counselled on academic matters. Besides, as mentioned in theme 3 , the role of 
principal is development of teacher leadership is undeniable. Limited control over administrative and academic matters, and too many tasks by the higher officials may discourage the teacher leaders. Therefore, future studies should examine the impact of principals' autocratic behaviour on the motivation level of teacher leaders.

\section{Key Learnings from the Review}

1. The role of a teacher leader is quite different from a traditional leader. Their influence is not limited to any office or classroom. In fact, it is spread over the whole school and community.

2. Teacher leaders perform various activities ranging from management tasks to teachers' counselling and involving parent or community for the betterment of the students in particular and for schools in general.

3. Key characteristics such as experience, position, and physical surroundings have a significant impact on teachers' opinions of teacher leadership. The age of teacher leaders, however, appears to be the most critical determinant.

4. Teachers' own beliefs about teacher leadership, the role of professional development and the role of principals are crucial for the development of teacher leadership among teachers.

5. The findings show that the main challenges to teacher leadership are a hard workload, a lack of time, teachers' aversion to change, and position ambiguity. Teacher leadership has also been found to be hampered by hierarchical structures and principal autocracy.

\section{CONCLUSIONS}

To conclude we can say that teacher leadership means that teachers are an agency to lead change and to guide organizational development and improvement. Teacher leaders motivate colleagues towards change and organizational goals; they promote pedagogical improvement within their multi-professional teams, lead curriculum work and support others in their efforts to achieve pedagogical improvement Harris (2003). This literature review aimed at exploring the perceptions about teachers about teacher leadership. This is significant because teachers are one of the most important agents for educational transformation. Extensive literature search helped the researchers gain access to many studies on the subject but only sixteen studies were finally selected on the basis of the inclusion criteria. The documents were closely studied and, as a result, four categories emerged. So, the close reading of the selected documents helped to find out and code the excerpts related to the goal of this study and the theme under discussion. The coding process was followed by organization of the findings and writing the report. The findings of the study clearly indicate 
that the area of teacher leadership has explored in developed countries such as US, Honk Kong, and Belgium (Flanders). Although studies exist which have been conducted in Qatar, Taiwan and Iran, no study could be shortlisted from the South-Asian context. In contexts like India, Pakistan, Bangladesh and Sri Lanka, teachers perform multi-perspective leadership roles. Therefore, it is essential to explore their perceptions and practices bring their voices into the mainstream literature on the subject.

Another point of consideration is that some correlational studies should be conducted to see the relationship between teachers' perceptions of teacher leadership and their practices. This is imperative because teachers' perceptions about teacher leadership are highly influenced by factors of experience, position and physical environment. However, the most important factor seems to be the age of teacher leaders. Moreover, in contexts where qualitative studies have been conducted, more mixed-method studies should be conducted as it is the most suitable approach to "examine trends and relationships using quantitative methods, or to explore individuals' experiences and perceptions about the problem using qualitative methods" (Phakiti, Costa, Plonsky, \& Starfield, 2018).

Lastly, it is suggested for future research that perceptions of teachers with different disciplinary backgrounds should also be considered as the perceptions of science teachers about teacher leadership may vary from those of language teachers. Since no substantial work has been done in the field in the developing countries, this literature review sums up the potential gaps that the future studies can fill with respect to teacher leadership.

\section{REFERENCES}

Aliakbari, M., \& Sadeghi, A. (2014). Iranian teachers' perceptions of teacher leadership practices in schools. Educational management administration $\mathcal{E}$ leadership, 42(4), 576-592. https:// doi.org/10.1177/1741143213510500

Angelle, P. S., \& Dehart, C. A. (2011). Teacher perceptions of teacher leadership: Examining differences by experience, degree, and position. Nassp Bulletin, 95(2), 141-160. https:// doi.org/10.1177/0192636511415397

Cheng, A. Y., \& Szeto, E. (2016). Teacher leadership development and principal facilitation: Novice teachers' perspectives. Teaching and Teacher Education, 58, 140-148. https://doi.org/10.1016/j.tate.2016.05.003

Chien, C. W. (2018). Taiwanese elementary school English teachers' perception of teacher leadership. Research in Education, 108(1), 46-61. https:// doi.org/10.1177/0034523718809390 
Cosenza, M. N. (2015). Defining Teacher Leadership: Affirming the Teacher Leader Model Standards. Issues in teacher education, 24(2), 79-99.

Grant, C., Gardner, K., Kajee, F., Moodley, R., \& Somaroo, S. (2010). Teacher leadership: a survey analysis of KwaZulu-Natal teachers' perceptions. South African Journal of Education, 30(3), 401-419. https://doi.org/10.15700/saje.v30n3a362

Harris, A. (2003). Teacher leadership as distributed leadership: heresy, fantasy or possibility? . School leadership E management, 23(3), 313-324. https:// doi.org/10.1080/1363243032000112801

Jacobs, J., Gordon, S. P., \& Solis, R. (2016). Critical issues in teacher leadership: A national look at teachers' perception. Journal of School Leadership, 26(3), 374-406. https:// doi.org/10.1177/105268461602600301

Katzenmeyer, M., \& Moller, G. (2009). Awakening the sleeping giant: Helping teachers develop as leaders. Corwin Press.

Lai, E., \& Cheung, D. (2015). Enacting teacher leadership: The role of teachers in bringing about change. Educational management administration $\mathcal{E}$ leadership, 43(5), 673-692. https:// doi.org/10.1177/1741143214535742

Margolis, J., \& Huggins, K. S. (2012). Distributed but undefined: New teacher leader roles to change schools. Journal of School Leadership, 22(5), 953-981. https://doi.org/105268461202200506

Neumerski, C. M. (2013). Rethinking instructional leadership, a review: What do we know about principal, teacher, and coach instructional leadership, and where should we go from here? Educational administration quarterly, 49(2), 310-347. https://doi.org/10.1177/0013161X12456700

Nicolaidou, M. (2010). Do primary school teachers in Cypriot schools see themselves as leaders? Echoing practitioners' voices on levers and barriers. Teacher development, 14(2), 225-239. https:// doi.org/10.1080/13664530.2010.494503

Olujuwon, T., \& Perumal, J. (2014). Nigerian secondary school teachers' perception towards teacher leadership. 58th Year Book on Teacher Education, 241-251.

Phakiti, A., Costa, P. D., Plonsky, L., \& Starfield, S. (2018). The palgrave handbook of applied linguistics research methodology. Springer.

Ross, D., Adams, A., Bondy, E., Dana, N., Dodman, S., \& Swain, C. (2011). Preparing teacher leaders: Perceptions of the impact of a cohort-based, job embedded, blended teacher leadership program. Teaching and Teacher Education, 27(8), 1213-1222. https:// doi.org/10.1016/j.tate.2011.06.005

Sawalhi, R., \& Chaaban, Y. (2019). Student teachers' perspectives towards teacher leadership. International Journal of Leadership in Education, 
251 | Kamran Akhtar Siddiqui et al.

22(4), 1-17. https:// doi.org/10.1080/13603124.2019.1666430

Schott, C., Roekel, H. V., \& Tummers, L. (2020). Teacher leadership: A systematic review, methodological quality assessment and conceptual framework. Educational Research Review, 31, 1-24. https://doi.org/10.1016/j.edurev.2020.100352

Sinha, S., \& Hanuscin, D. L. (2017). Development of teacher leadership identity: A multiple case stud. Teaching and Teacher Education, 63, 356-371. https://doi.org/10.1016/j.tate.2017.01.004

Siti, I. A. (2011). Teacher leadership in improving the quality of teaching in a national secondary school in Shah Alam. Unpublished master thesis, Universiti Malaya, Kuala Lumpur.

Struyve, C., Meredith, C., \& Gielen, S. (2014). Who am I and where do I belong? The perception and evaluation of teacher leaders concerning teacher leadership practices and micropolitics in schools. Journal of Educational Change, 15(2), 203-230. https://doi.org/10.1007/s10833-013-9226-5

Szeto, E., \& Cheng, A. Y. N. (2018). Principal-teacher interactions and teacher leadership development: Beginning teachers' perspectives. International Journal of Leadership in Education, 21(3), 363-379. https://doi.org/10.1080/13603124.2016.1274785

Vries, H. D., Bekkers, V., \& Tummers, L. (2016). Innovation in the public sector: A systematic review and future research agenda. Public administration, 94(1), 146-166. https://doi.org/10.1111/padm.12209

Zydziunaite, V., Kontrimiene, S., Ponomarenko, T., \& Kaminskiene, L. (2020). Challenges in Teacher Leadership: Workload, Time Allocation, and Self-Esteem. European Journal of Contemporary Education, 9(4), 948-962. 